\title{
ARCA VISNU CIBUAYA II \\ DALAM PERBANDINGAN
}

Oleh: Solarti V.S.

Untuk mempelajari bentuk-bentuk arca, dalam hal ini arca-arca dewa, harus diperhatikan apa yang mendasari pembuatan arca tersebut. Perwujudan dewa ke dalam bentuk arca disebabkan oleh adanya dorongan untuk mengkonkritkan bentuk dewa-dewa tersebut yang semula merupakan suatu gambaran yang abstrak. Dengan tujuan itu kemudian dewadewa diwujudkan dalam bentuk yang dapat dilihat dan diraba, yaitu dalam bentuk arca.

Untuk membedakan arca yang satu dengan lainnya dapat dilihat dari ciri yang menunjukkan kekhasan arca dewa tersebut. Arca-arca dewa dibuat berdasarkan ketentuan-ketentuan yang terdapat dalam kitab Cilpasas tra, yaitu sebuah kitab yang berisi ketentuan-ketentuan untuk membuat arca dan pahatan-pahatan di India. Ketentuan-ketentuan itu pada umumnya dipatuhi oleh para seniman pembuat arca, thususnya dalam pembuatan arca dewa yang memang tidak bisa dibuat sembarangan. Walaupun demikian dalam beberapa hal terdapat perkecualian dimana ketentuan-ketentuan tersebut adakalanya tidak dipenuhi secara mutlak. Dalam hal ini para seniman membuat arca-arca dewa sesuai dengan perkembangan citai rasa yang diselaraskan dengan kondisi setempat.

Hal inilah yang menimbulkan variasi dan gaya tertentu yang merupakan ciri dari suatu daerah maupun periode tertentu. Meskipun demikian, tampak bahwa didalam pembuatan arca-arca dewa tujuannya bukan sematamata untuk mencapai suatu keindahan saja tetapi lebih ditujukan pada latar belakang kerohanian (Soetjipto Wirjosoeparto, 1956: 5).

Ditemukannya arca Visnu Cibuaya I dan II di Jawa Barat menunjukkan masuknya pengaruh kebudayaan dan keagamaan Hindu di Jawa. Pengaruh tersebut mungkin tidak langsung datang ke Jawa, tetapi sudah melalui negara atau daerah lain di Asia Tenggara. Oleh karena itu, dalam menelaah peninggalan-peninggalan purbakala dj Indonesia, ada baiknya jika melihat pula ke negara-negara tetangga di Asia Tenggara. Tidak dapat diabaikan pula bahwa dalam proses adaptasi suatu kebudayaan baru, unsur kebudayaan lokal ikut memainkan peran yang cukup penting. Hal ini akan menimbulkan perpaduan antara keduanya yang menghasilkan suatu kebudayaan yang memiliki corak tersendiri. Seandainya terdapat perbedaan antara peninggalan purbakala yang satu dengan lainnya, baik dalam bentuk maupun gaya, kemungkinan besar hal itu disebabkan karena adanya perkembangan waktu maupun situasi serta unsur kebebasan dari para pembuat arca didalam menyesuaikan hasil karya dengan cita rasa.

Dalam kesenian India terkenal adanya 6 ketentuan pokok yang harus diperhatikan dalam membuat suatu karya seni (termasuk didalaninya seni arca/pahat), yaitu: 
a. Rüpabheda: perbedaan macam-macam benda dilihat dari bentuknya.

b. Pramanam: benda harus mempunya ukuran yang tepat dan keseimbang an bentuk.

c. Sadrcyam: benda harus digambarkan dalam bentuk yang sesungguhnya dan ini dapat dicapai melalui meditasi atau yoga.

d. Varnilkabhaigam: permainan warna untuk menimbulkan hasil yang diinginkan.

e. Lavanya: keindahan yang timbul dari hasil ciptaan itu sendiri.

f. Bhava: permainan perasaan (Soetjipto Wirjosoeparto, 1956: 8-10).

Ketentuan-ketentuan tersebut berlaku untuk semua arca, baik dalam agama Hindu maupun agama Budha. Arca dewa dalam agama Budha biasanya lebih mudah dikenal daripada arca dewa dalam agama Hindu. Hal ini disebabkan oleh karena arca dewa dalam agama Budha biasanya digambarkan lebih sederhana dengan wujud yang lebih manusiawi. Berbeda dengan arca dewa dalam agama Hindu dimana arca dewa yang satu dengan lainnya memiliki ciri yang berbeda dengan jumlah serta variasi yang beraneka ragam.

Dalam agama Hindu dikenal adanya 3 dewa tertinggi, yakni Brahma, Visnu dan Civa. Ketiganya dikenal dengan sebutan Trimurti. Trimurtisendiri mempunyai arti tiga badan, yakni Brahma sebagai dewa pencipta alam semesta; Visnu sebagai dewa pemelihara dan Civa sebagai dewa perusak atau pembinasa. Diantara ketika dewa tsb. yang paling banyak dipuja adalah Visnu dan Civa, terbukti dengan timbulnya 2 aliran besar dalam kebaktian keagamaan Hindu yakni Vaisnava dan Caiva (A.C. Bouquet, 1948: 91-97). Vaisnava adalah suatu aliran yang menganggap Visnu sebagai dewa tertinggi dan dipuja melalui avatara-avataranya sedangkan Caiva merupakan aliran yang menganggap Civa sebagai dewa tertinggi. Walaupun demikian, kedua aliran ini tidak mengingkari adanya Trimurti.

Sebelum berbicara tentang gaya dan ciri suatu arca, dalam hal ini arca Visnu, khususnya arca Visnu Cibuaya II, harus dilihat dahulu mengenai asal mula dikenalnya dewa terseb́ut yang kemudian diwujudkan dalam bentuk arca. Seperti telah diketahui, setelah berakhirnya masa kebudayaan lembah sungai Indus, di India muncul adanya dinasti-dinasti yang dimulai dengan dinasti Maurya 322-185 S.M. (Benjamin Rowland, 1967: 59). Sejak jatuhnya dinasti tersebut hingga sekitar abad $\mathbf{\gamma}$. Hinduisme mulai tampil secara bertahap hingga pada bentuknya seperti yang dapat di lihat sekarang (H.G.Rawlinson, 1952: 123). Hinduisme sendiri merupakan suatu gabungan antara unsur-unsur yang terdapat dalam kebudayaan Arya dan Dravida. Dewa-dewa dalam kebudayaan lama mundur atau lebur menjadi Trimurti dalam agama Hindu. Dalam hal ini, dewa Visnu dikatakan berasal dari dewa matahari pada kepercayaan kuno. Dengan kata lain, dewa Visnu merupakan kelanjutan dari dewa matahari yang dikenal pada masa kebudayaan Arya dan Dravida. Seperti yang terlihat saat ini, salah satu atribut dewa Visnu adalah cakra yang dianggap sebagai penggambaran matahari (J.Gonda, 1954: 97). 
Membicarakan suatu arca dapat ditinjau dari 2 segi, yakni:

1. segi ikonografinya, mencakup tanda-tanda yang memberi arti tertentu pada arca tersebut dan

2. segi seninya, yang membicarakan keindahan yang terdapat di dalamnya.

Disini akan dibicarakan segi ikonografi dari arca Visnu Cibuaya II, tetapi sebelumnya akan dibicarakan juga mengenai gambaran arca Visnu secara umum.

Dewa Visnu biasa digambarkan berkepala satu dan bertangan empat, tetapi adakalanya bertangan dua atau delapan. Atribut-atribut yang lazim terdapat pada tangannya adalah cakra (roda), lotus (teratai), cankkha (terom pet kerang) dan gada atau tongkat. Selain itu terdapat juga variasi dalam atributnya, misalnya pedang, tasbih, panah dan lain-lain. Pada kepalanya terdapat kiritamakuta, yaitu mahkota yang berbentuk kerucut. Di leher terdapat hara (kalung), di dada melintang yajinopavita (tali kasta berupa ular), di pinggang terdapat udarabandha (ikat pinggang). Pada lengannya terdapat keyüra (gelang lengan) dan kankana (gelang tangan) pada pergelangan tangannya. Selain itu terdapat pula 2 tanda khusus pada dadanya, 'yakni srivatea dan knustubhamani (J.Gonda, 1954: 100). vahana (ken daraan) dewa Visnu adalah garuda.

Arca Visnu Cibuaya II mempunyai beberapa keistimewaan yang mung kin merupakan variasi bila dibandingkan dengan beberapa arca Visnu lainnya yang terdapat di berbagai tempat di Indonesia, terutama dari masa yang sejaman dengan arca Visnu Cibuaya II. Arca-arca Visnu tersebut antara lain adalah arca Visnu dari candi Prambanan dan arca Visnu dari candi Banon.

Arca Visnu Cibuaya II sekarang tersimpan di Museum Pusat Jakarta dengan nomer 8416, ditemukan di desa Cibuaya, Krawang, Jawa Barat (Soetjipto Wirjosoeparto, 1963: 170). Tinggi arca berikut lapiknya adalah $48 \mathrm{Cm}$ dan terbuat dari batu hitam yang mengkilat. Arca ini berdiri dengan sikap samapadasthanaka, yaitu sikap berdiri tegak atau membentuk satu garis lurus dari mahkota di kepala sampai satu titik di tengah tumit melalui pusat (D.N. Shukla, tanpa angka tahun: 130).

Raut mukanya berbentuk seperti daun sirih, sedangkan mata digambarkan setengah terbuka dengan kelopak yang menutupi sebagian matanya. Mulut arca menyerupai bentuk segi tiga dengan sudut-sudut mulut naik ke arah pipi. Di kedua telinganya terdapat kundala yang panjang menyentuh bahu dengan ujung-ujung kundala yang berbentuk bulatan. Stela arca ini memiliki puncak yang berbentuk setengah lingkaran. Sirascakra (lingkaran cahaya) di belakang kepala hampir tidak terlihat, tetapi dapat diperkirakan bahwa sirascakra tersebut polos tanpa hiasan. Mahkota yang dikenakan adalah kiritamakuta, yaitu mahkota dengan bentuk kerucut yang ba- 
gian dasarnya lebih kecil daripada puncaknya. Di bagian depan mahkota itu terdapat hiasan dengan bentuk bundar yang mungkin merupakan bagian dari ornamen bunga.

Melihat bentuk tubuhnya, dapat dikatakan bahwa arca ini berdada bidang dengan pinggang yang ramping. Pada lehernya tidak terdapat hara dan pada dadanya tidak terdapat upavita. Arca Visnu Cibuaya II ini memiliki 4 tangan. (caturbhuja) yang pada /engannya terdapat keyura berbentuk segi tiga. Adapun padapergelangan tangannya terdapat kankana. Atribut yang terdapat pada keempat tangannya adalah sebagai berikut: pada tangan kiri atas terdapat cankha, tangan kiri bawah memegang gada, tangan kanan atas mungkin memegang cakra (tidak begitu jelas terlihat) dan pada tangan kanan bawah terdapat vulva. Kakinya arca terlihat lurus tegap, seolah-olah ditanam pada lapik arca. Pakaiannya berupa paridhana atau jubah panjang yang menyentuh mata kaki dan memakai ikat pinggang (katibandha) yang dibagi dalam beberapa bagian dengan garis-garis vertikal dimana pada bagian pusatnya dihiasi dengan ornamen. Pergelangan kaki arca ini tidak memakai nupura (gelang kaki). Lapit arca dihias dengan garis-garis vertikal yang membagi lapik menjadi 5 bagian. Dilihat secara keseluruhan, arca Visnu Cibuaya II ini miskin dalam hal ornamen.

Sebagai perbandingan akan dibicarakan pula sedikit tentang arca Visnu daricandi Prambanan dan arca Visnu dari candi Banon. Arca Visnu dari candi Banon saat ini berada di Museum Pusat Jakarta. Tinggi arca ini $206 \mathrm{Cm}$. Sirascakra yang terdapat di belakang kepala memiliki bentuk bulat telur. Mahkota yang dipakainya adalah kiritamakuta. Di kedua daun telinganya terdapat kundala yang panjangnya mencapai bahu, sedangkan pada lehernya yang indah dan berlipat-lipat terdapat hara. Upavita terdapat pada dada yang melintang dari bahu kiri hingga pinggang kanan. Selain itu terdapat juga kaustubhamani dan udarabandha. Di bawah udarabandha terapat 3 buah katibandha berbentuk rantai dimana pada bagian bawah katibandha itu masih terdapat 2 ikat pinggang yang ujungnya menjurai hingga batas lutut.

Arca Visnu dari candi Banon ini memiliki 4 tangan dengan atribut yang tidak diketahui karena bagian tangan hingga batas siku telah hilang. Keyura dengan bentuk segi tiga terdapat pada keempat lengannya. Arca ini mengenakan kain polos dengan bagian kiri lebih panjang dari pada bagi an kanan. Arca tersebut digambarkan berdiri tegak di atas lotus ganda.

Di sebelah kiri depan bantalan lotus terdapat pula alas lain dalam bentuk lotus yang lebih kecil. Alas seperti ini biasanya digunakan sebagai tempat sandar sebuah gada. Pada bagian belakang arca terdapat garuda dalam posisi jongkok dengan sayap terbuka yang menempel pada bagian belakang kaki (betis) arca. Arca Visnu dari candi Banon ini diperkirakan berasal dari sekitar abad $9 \mathrm{M}$.

Arca Visnu lain yang akan dibicarakan disini adalah arca Visnu dari candi Visnu yang masuk dalam kompleks candi Loro Jonggrang di Prambanan. Arca ini bisa dikatakan utuh dan dipahatkan berdiri bersandar pada stela. Di belakang kepala terdapat sirascakra polos tanpa hiasan. 
Mahkotanya adalah kiritamakuta. Mata arca digambarkan tertutup; di kedua daun telinga terdapat kundala yang panjang menjulur sampai bahu. dan di lehernya terdapat hara.

Dilihat secara keseluruhan, bentuk tubuh arca yang ramping ini dikenal dengan sebutan simha kati (R.C. Majumdar, 1950: 535). Pada bagian dadanya terdapat upavita dan di antara dada dan perut melingkar udarabandha. Di bagian pinggang terdapat katibandha yang disimpulkan di bagian tengah dan sisanya menjurai sampai lutut. Arca ini dipahat dengan memakai jubah panjang hingga mata kaki. Arca Visnu tersebut memiliki 4 tangan dengan atribut yang dibawa pada tangan kanan atas berupa cakra, pada tangan kiri atas berupa cankha yang bersayap. Tangan kanan bawah bertopang pada sebuah gada sedangkan pada telapak tangan kiri bawah terdapat tanda yang berbentuk segi tiga ujungnya menghadap ke bawah. Arca itu juga memakai keyura yang berbentuk segitiga dan pada pergelangan tangan terdapat kankana. Adapun pergelangan kaki arca memakai nupura.

Arca Visnu dari candi Visnu ini berdiri di atas padmasana dimona pada bagian bawah padmasana tadi terdapat yoni. Arca ini diperkirakan berasal dari sekitar abad $9 \mathrm{M}$.

III

Seperti telah disebutkan di atas, arca Visnu Cibuaya II ini mempunyai beberapa keistimewaan dalam pahatan maupun bahannya. Bahan yang digunakan dalam pembuatan arca tersebut adalah batu hitam yang biasa disebut kastipathar. Batu hitam semacam ini jarang dijumpai di Indonesia dalam pembuatan pahatan tetapi biasa digunakan dalam membuat obyekobyek seni di Bengal pada masa kesenian Pala (R.C. Majumdar, 1943: 429). Masa kesenian Pala itu berkembang di India Utara sejak tahun 730 M. hingga $1197 \mathrm{M}$.

Stela yang terdapat pada arca Visnu Cibuaya II puncaknya berbentuk bundar. Stela dengan bentuk semacam ini didapati pada pahatan-pahatan dari kesenian Pala sejak abad 9 M. (Soetjipto Wirjosoeparto, 1963: 175). Mahkota yang dipakai adalah kiritamakuta tetapı bagian dasarnya lebih kecil daripada bagian puncaknya. Mahkota semacam ini didapatkan pula pada arca-arca Visnu dari Pechaburi dan C'aiya (Siam). Arca Visnu dari Pechaburi berasal dari abad 11 M., sedangkan arca Visnu C'aiya berasal dari abad 8M. (L Frederic, 1964: 140-141).

Mata arca Visnu Cibuaya II memiliki bentuk setengah terbuka dengan kelopak menutupi sebagian bola matanya. Kelopak yang menutupi sebagian bola mata merupakan ciri kesenian Gupta (India Utara) yang berkembang sejak abad 5 M. hingga abad 6 M. (S. Kramrisch, 1933: 63-67). Sedangkan bentuk mata yang setengah terbuka merupakan ciri kesenian Pala dari Bihar dan Bengal (India Utara) yang berkembang pada abad $8 \mathrm{M}$. Meli hat kenyataan ini, dapat diperkirakan bahwa bentuk mata arca Visnu Cibuaya II merupakan bentuk peralihan dari kesenian Gupta ke kesenian Pala.

Atribut yang berada pada tangan kanan bawah arca Visnu Cibuaya II berupa vulva.J. Gonda berpendapat bahwa cankha dapat juga dianggap 
sebagai penggambaran vulva. Hal ini untuk menghubungkan Visnu dengan kesuburan (J. Gonda, 1954: 100-101). Atribut berupa vulva didapatkan pula pada beberapa arca Visnu dari Hmawza dan Nat Hlaung Hyaung (Birma). Arca Visnu Hmawza berasal dari abad 8 M., sedangkan arca Visnu Nat Hlaung Hyaung berasal dari abad 10 M. (L. Frederic, 1964: 22, 53-54). Atribut pada tangan kiri bawah adalah gada. Cara memegang gada pada arca Visnu Cibuaya II ini seolah-olah gada tersebut digenggam dalam tangannya. Hal semacam ini didapatkan pula pada arca-arca dari masa kesenian Pala di India dan juga pada arca-arca Visnu dari Birma. Cara memegang gada di India biasanya adalah tangan seolah-olah hanya menyentuh bagian atas dari gada yang tersandar di lantai. (Soetjipto Wirjosoeparto, 1963: 174).

Lapik arca Visnu Cibuaya II dihiasi dengan goresan berjumlah 5 buah. Hal semacam ini didapati juga pada arca dari masa kesenian Pala dimana lapik dihiasi dengan goresan-goresan dalam jumlah ganjil, misalnya 3,5, 7 dan 9. Arca Visnu yang lapiknya dihiasi goresan berjumlah 5 juga didapati di Malaysia Tengah dan Siam yang berasal dari abad 8 M. (J.Boisselier, 1959: 216).

Dengan melihat sekali lagi atas ciri serta perbandingan tersebut di atas, dapat diperkirakan bahwa arca Visnu Cibuaya II itu berasal dari sekitar abad $9 \mathrm{M}$. Sebetulnya alasan-alasan yang dikemukakan di atas belum mencukupi, tetapi sampai sejauh ini baru hal-hal tersebut yang dapat dibicarakan.

\section{Kepustakaan:}

Boisselier, J.,

1959

Bouquet, A.C., 1948

Frederic, L., 1964

Gonda, J., 1954

Kramrisch, S., 1933

Majumdar, R.C., 1943
: "Le Visnu de Tjibuaja (Java Occidental) et la Statuaire du Sud-Est Asiatique", Artibus Asiae, Vol. XXII (3), Einsiedeln, Switzerland: Verlagsanstalt Benziger \& Co. A.G.

: Hinduism, London: Hutchinson's University Library.

: Sud-Est Asiatique, Paris: Arts et Metiers Graphique.'

: Aspects of Early Visnuism, Utrecht: NV A. Oosthoek's Uitgevers Mij.

: 'Indian Sculptural", The Heritage of India Series, London: Oxford University Press.

: The History of Bengal, Vol. I, Dacca: tanpa nama penerbit. 
Majumdar, R.C., (Et. Al) : An Advanced History of India, London: Mac 1950 Millan \& Co. Ltd.

Rawlinson, H.G., 1952

: India, A Short Cultural History, London: The Cresset Press.

Rowland, B.,

: The Pelican History of Art, Harmondsworth, Middlesex: Penguin Books Ltd.

Shukla, D.N., 1967

: "Hindu Canons of Iconography and Painting", tanpa angka tahun Vastu Sastra, Vol. II, Gorakhpur: tanpa nama penerbit.

Soetjipto Wirjosoeparto, : Sedjarah Seni Artja India, Jakarta: Kalimo1956 sodo.

: "The Second Vishnu Image of Tjibuaja in 1963 West Java", M.I.S.I., I, No. 2, Jakarta: Jajasan Penerbitan Karja Sastra. 